\title{
Optimization of the Synthesis of Diclofenac Derivatives with Hydrazone Structure and In Vitro Evaluation of the Anti-Inflammatory Potential
}

\author{
ALIN FOCSA ${ }^{1}$, ANDREEA IACOB ${ }^{1 *}$, IOANA VASINCU ${ }^{1}$, SANDRA CONSTANTIN $^{1}$, \\ LOREDANA ANDRIESCU ${ }^{1}$, ALEXANDRU SAVA ${ }^{1}$, FREDERIC BURON ${ }^{2}$, \\ SYLVAIN ROUTIER ${ }^{2}$, MARIA APOTROSOAEI ${ }^{1 *}$, LENUTA PROFIRE ${ }^{1}$ \\ ${ }^{1}$ University of Medicine and Pharmacy "Grigore T. Popa" from Iasi, Faculty of Pharmacy, Department of Pharmaceutical \\ Chemistry, 16 Universității Str., 700115, Iasi, România \\ ${ }^{2}$ University of Orleans, Institute of Organic and Analytical Chemistry, Pole de Chimie, Chartres Str., 45067, Orleans, \\ France
}

Abstract. The aim of the study was to optimize the synthesis of diclofenac derivative with hydrazones structure in order to obtain higher yields and purity by variation of different parameters such as: ratio between reactants, solvent, catalyst, temperature, time of reaction and method used. The antiinflammatory effects of diclofenac derivatives were evaluated using in vitro assays: albumin denaturation and erythrocyte membrane stability. The obtained results showed that the effect of the tested derivatives is increasing with the concentration, the best results being obtained at the concentration of $125 \mu \mathrm{g} / \mathrm{mL}$ (albumin denaturation assay), respectively $111.11 \mu \mathrm{g} / \mathrm{mL}$ (erythrocyte membrane stability assay). The most active compound was $4 \mathrm{~d}$ which showed the highest inhibition effect on albumin denaturation and an appreciable effect on erythrocyte membrane stability, in comparation with diclofenac, used as drug reference.

Keywords: diclofenac, hydrazone, optimization, anti-inflammatory effect

\section{Introduction}

Non-steroidal anti-inflammatory drugs (NSAIDs) are among the oldest and most successful drugs known in modern medicine to decrease pain and inflammation by inhibiting prostaglandins synthesis, but unfortunately their use is associated with a number of serious side effects. NSAIDs, such as diclofenac, are indicated for improvement of all degrees inflammation associated with a large number of conditions, including arthritic disorders, acute musculoskeletal disorders and other painful conditions resulted from trauma. Using NSAIDs have been reported gastrointestinal bleeding, ulceration or perforations, which can be fatal, and can occur at any time during treatment, with or without a history of serious gastrointestinal disorders. If gastrointestinal bleeding or ulceration occurs to patients who receive diclofenac, treatment will be ended $[1,2]$.

It is important to note that cyclooxygenase-1 (COX-1) and cyclooxygenase-2 (COX-2) enzymes play an important role in inflammation. The modifying the structure of the classical NSAIDs is a common practice which was used over the years in order to improve the biological effects of parent molecule. Hydrazone derivatives represent an attractive group of compounds with a broad spectrum of pharmacological and biological characteristics [3,4]. In order to improve the pharmacological profile of diclofenac, some hydrazone derivatives were synthesized by researchers $[5,6]$.

The aim of this study was to optimize the method for synthesis of diclofenac derivatives with hydrazone structure in order to apply it for extending the diclofenac hydrazone derivatives library. The synthesized derivatives were evaluated for antiinflmmatory effects using in vitro assays.

In vitro anti-inflammatory assays are important tools to select the most active derivatives to be tested using in vivo assays, and so, the use of a high number of animals is avoided [7,8]. Proteins denaturation is a well - documented cause of inflammation and the anti-inflammatory drugs, such as

\footnotetext{
*email: andreea.panzariu@umfiasi.ro, apotrosoaei.maria@umfiasi.ro
} 
diclofenac, salicylic acid etc. have shown dose-dependant ability to inhibit the thermally induced protein denaturation [8]. It is also known that inflammation is linked with a significant release of lysosomal components and so drugs that increase the stability of cells membrane, as human red blood cell, could reduce the inflammation process [7].

\section{Materials and methods}

\subsection{Chemistry}

\section{Reagents and equipments}

Diclofenac sodium salt, hydrazine hydrate 64\%, 4-methyl-benzaldehyde, ethanol, methanol, dioxane, sulfuric acid, were purchased from Redox Lab Supplies Com S.R.L. Thin layer chromatography F254 plates and deuterated dimethyl sulfoxide (DMSO- $\mathrm{d}_{6}$ ) were purchased from Sigma Aldrich. Microwave irradiation was carried out using Biotage Initiator System (France), at a standard absorbance level (300 W maximum power). The melting points were measured using a Buchi Melting Point B-540 apparatus and they are uncorrected. The infrared (IR) spectra were recorded on a ThermoNicolet AVATAR 320 AEK0200713 FT-IR Spectrometer (Canada), at a resolution of $4 \mathrm{~cm}^{-1}$ after 6 scans in the $4000-500 \mathrm{~cm}^{-1}$ range. The spectra were processed using the Omnic Spectra Software. The ${ }^{1} \mathrm{H}-\mathrm{NMR}(400 \mathrm{MHz})$ and ${ }^{13} \mathrm{C}-\mathrm{NMR}(101 \mathrm{MHz})$ spectra were recorded with a Bruker Avance Spectrometer $400 \mathrm{MHz}$ (Germany), using tetramethylsilane (TMS) as internal standard and DMSO- $\mathrm{d}_{6}$ as solvent. The chemical shifts were shown in $\delta$ values (ppm). The mass spectra were recorded using a Bruker MaXis Ultra-High Resolution Quadrupole Time-of-Flight Mass Spectrometer (Germany).

\section{Synthesis}

In order to optimize the synthesis of diclofenac derivatives different parameters were varied such as: the molar ratio between reagents, the solvent, temperature, the reaction time, the catalyst and the method used (classic or microwaves). The synthesis was monitored by thin layer chromatography (TLC) using different eluents and the structure of the derivatives was proved by infrared (IR), nuclear magnetic resonance $\left({ }^{1} \mathrm{H}-\mathrm{NMR},{ }^{13} \mathrm{C}-\mathrm{NMR}\right)$ and high resolution mass spectrometry (HR-MS) $[9,10]$.

The synthesis of the diclofenac derivatives with hydrazone structure was performed according to the Scheme 1.

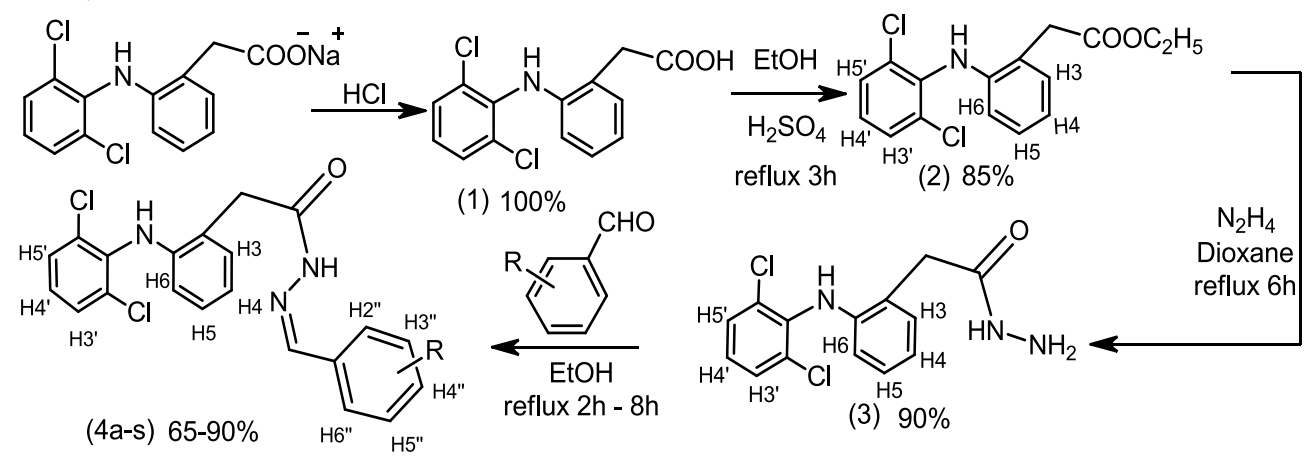

Scheme 1. The synthesis of diclofenac derivatives with hydrazone structure (4a-s)

\subsection{Serum albumin denaturation assay}

Reagents and solvents: saline phosphate buffer, bidistilled water, methanol, DMSO, bovine serum albumin (BSA), diclofenac, diclofenac derivatives (4a-s).

Procedure: stock solutions of $1 \mathrm{mg} / \mathrm{mL}$ in DMSO were prepared using diclofenac and diclofenac derivatives (4a-s). From each stock solution a volume of $50 \mu \mathrm{L}, 100 \mu \mathrm{L}, 200 \mu \mathrm{L}$ and $500 \mu \mathrm{L}$ was measured and methyl alcohol was added to $1000 \mu \mathrm{L}$. Then, a sample of $30 \mu \mathrm{L}$ from each dilution was added to $3 \mathrm{~mL}$ of $1 \%$ bovine serum albumin solution. The concentration of the tested derivatives in the obtained samples was $12.5 \mu \mathrm{g} / \mathrm{mL}, 25 \mu \mathrm{g} / \mathrm{mL}, 50 \mu \mathrm{g} / \mathrm{mL}$ and $125 \mu \mathrm{g} / \mathrm{mL}$, respectively. A mixture of $30 \mu \mathrm{L}$ of methanol and $3 \mathrm{~mL}$ of $1 \%$ bovine serum albumin was used as control. The samples and the 
control were incubated for $20 \mathrm{~min}$ at $37^{\circ} \mathrm{C}$, then $5 \mathrm{~min}$ at $72^{\circ} \mathrm{C}$, cooled at room temperature for $10 \mathrm{~min}$ and then $1 \mathrm{~mL}$ of phosphate buffered saline $\mathrm{pH} 7.2$ was added. The turbidity of the samples and control was read at $416 \mathrm{~nm}$ against distilled water. The capacity of the tested derivatives to inhibit serum albumin denaturation was calculated using the following formula [11]:

Denaturation inhibition $(\%)=\left[\left(\mathrm{A}_{\mathrm{c}}-\mathrm{A}_{\mathrm{s}}\right) / \mathrm{A}_{\mathrm{c}}\right] \times 100$

in which:

$\mathrm{A}_{\mathrm{c}}$ - the absorbance value of the control;

$\mathrm{A}_{\mathrm{s}}$ - the absorbance value of the sample.

For each sample the effective concentration $\left(\mathrm{EC}_{50}\right)$ was calculated by linear regression analysis and diclofenac $(1 \mathrm{mg} / \mathrm{mL})$ was used as the reference drug. All experiments were performed in triplicate.

\subsection{Erytrocyte membrane stabilization assay}

Reagents and solvents: phosphate buffer $(p \mathrm{H}=7.4), \mathrm{NaCl}$ solution $(0.36 \%, 0.85 \%)$, erythrocyte suspension (HRBC-human red blood cell, solution $10 \%$ (v/v), HRBC in $0.85 \% \mathrm{NaCl}$ solution, $p \mathrm{H} 7.2$, DMSO, diclofenac, diclofenac derivatives (4a-s).

Procedure: stock solutions of $1 \mathrm{mg} / \mathrm{mL}$ in DMSO were prepared using diclofenac and diclofenac derivatives (4a-s). From each stock solution, a volume of $100 \mu \mathrm{L}, 200 \mu \mathrm{L}$ and $500 \mu \mathrm{L}$ was measured and $0.85 \% \mathrm{NaCl}$ solution was added to $1000 \mu \mathrm{L}$. To each sample $1 \mathrm{~mL}$ of phosphate buffer, $2 \mathrm{~mL}$ of $0.36 \% \mathrm{NaCl}$ solution and $0.5 \mathrm{~mL}$ of $\mathrm{HRBC}$ solution $(10 \% \mathrm{v} / \mathrm{v})$ were added. The concentration of the tested derivatives in the obtained samples was $22.22 \mu \mathrm{g} / \mathrm{mL}, 44.44 \mu \mathrm{g} / \mathrm{mL}$ and $111.11 \mu \mathrm{g} / \mathrm{mL}$, respectively. The control was prepared by adding of $1 \mathrm{~mL}$ of $0.85 \% \mathrm{NaCl}$ solution to a mixture of 1 $\mathrm{mL}$ of phosphate buffer, $2 \mathrm{~mL}$ of $0.36 \% \mathrm{NaCl}$ solution and $0.5 \mathrm{~mL}$ of $\mathrm{HRBC}[12,13]$.

The samples and the control were incubated at $37^{\circ} \mathrm{C}$ for $30 \mathrm{~min}$, then centrifuged at $3000 \mathrm{rpm}$ for $20 \mathrm{~min}$. The absorbance of the supernatant was read at $560 \mathrm{~nm}$ against distilled water. The capacity of the tested derivatives to preserve erythrocyte membrane expressed as stability (\%), was calculated using the following formula [14]:

Stability $(\%)=100-\left[\left(\mathrm{A}_{\mathrm{s}} / \mathrm{A}_{\mathrm{c}}\right) \times 100\right]$

in which:

$\mathrm{A}_{\mathrm{c}}$ - the absorbance value of the control;

$A_{s}$ - the absorbance value of the sample.

For each sample the effective concentration $\left(\mathrm{EC}_{50}\right)$ was calculated by linear regression analysis and diclofenac $(1 \mathrm{mg} / \mathrm{mL})$ was used as the reference drug. All experiments were performed in triplicate.

\section{Results and discussions}

\subsection{Chemistry}

Optimization of the synthesis of ethyl 2-[2-(2,6-dichlorophenylamino)phenyl]acetate (2) was performed using different procedures reported in the literature $[15,16]$. The influence of different parameters, such as the ratio between diclofenac (1) and $\mathrm{H}_{2} \mathrm{SO}_{4}$ as catalyst (1:0.1, 1:0.2, 1:0.25, 1:0.3), the time of reaction (between $30 \mathrm{~min}$ to $6 \mathrm{~h}$ ) and the method used (classic or microwaves) on the reaction yield is presented in Table 1 .

It was observed that the highest yield $(85 \%)$ was obtained using the following conditions: ratio between diclofenac and $\mathrm{H}_{2} \mathrm{SO}_{4}$ of $1 \mathrm{eq}: 0.25$ eq., heating at $80^{\circ} \mathrm{C}$ (reflux) for $3 \mathrm{~h}$ and ethanol as solvent $(20 \mathrm{~mL})$.

Table 1. The different reaction conditions used to optimize the esterification reaction of diclofenac

\begin{tabular}{|c|c|c|c|c|c|c|c|c|}
\hline No. & Diclofenac & & $\mathbf{H}_{2} \mathbf{S O}_{\mathbf{4}}$ & Solvent & $\mathbf{T}\left({ }^{\circ} \mathbf{C}\right)$ & Time $(\mathbf{m i n} / \mathbf{h})$ & Method used & Yield \\
\hline 1. & 1 eq. & & 0.1 eq. & ethanol & 80 & $1 \mathrm{~h}$ & classic & $55 \%$ \\
\hline 2. & 1 eq. & & 0.1 eq. & ethanol & 80 & $3 \mathrm{~h}$ & classic & $70 \%$ \\
\hline
\end{tabular}




\begin{tabular}{|c|c|c|c|c|c|c|c|c|}
\hline 3. & 1 eq. & & 0.1 eq. & ethanol & 80 & $30 \mathrm{~min}$ & $\mathrm{mw}$ & $72 \%$ \\
\hline 4. & 1 eq. & & 0.2 eq. & ethanol & 80 & $3 \mathrm{~h}$ & classic & $79 \%$ \\
\hline 5. & 1 eq. & & 0.2 eq. & ethanol & 80 & $45 \mathrm{~min}$ & $\mathrm{mw}$ & $81 \%$ \\
\hline 6. & 1 eq. & & 0.25 eq. & ethanol & 80 & $2 \mathrm{~h}$ & classic & $80 \%$ \\
\hline 7. & 1 eq. & & 0.25 eq. & ethanol & 80 & $3 \mathrm{~h}$ & classic & $85 \%$ \\
\hline 8. & 1 eq. & & 0.25 eq. & ethanol & 80 & $6 \mathrm{~h}$ & classic & $78 \%$ \\
\hline 9. & 1 eq. & & 0.25 eq. & ethanol & 80 & $45 \mathrm{~min}$ & mw & $81 \%$ \\
\hline 10. & 1 eq. & & 0.30 eq. & ethanol & 80 & $2 \mathrm{~h}$ & classic & $81 \%$ \\
\hline 11. & 1 eq. & & 0.30 eq. & ethanol & 80 & $3 \mathrm{~h}$ & classic & $79 \%$ \\
\hline 12. & 1 eq. & & 0.30 eq. & ethanol & 80 & $45 \mathrm{~min}$ & mw & $72 \%$ \\
\hline
\end{tabular}

$\mathrm{T}\left({ }^{\circ} \mathrm{C}\right)=$ temperature; $\mathrm{mw}=$ microwave;

Yield: 85\%; m.p: $72^{\circ} \mathrm{C}$; IR (cm $\left.{ }^{-1}\right): 3145,3090,3016(-\mathrm{NH}-), 2355,1588,1298\left(\mathrm{CH}_{\mathrm{Ar}}\right), 1696$ (-CO), 897, 765, 744, (-C-Cl); ${ }^{1} \mathrm{H}-\mathrm{NMR}\left(400 \mathrm{MHz}, \mathrm{DMSO}-\mathrm{d}_{6}, \delta \mathrm{ppm}\right): 1.22\left(3 \mathrm{H}, \mathrm{m}, \mathrm{CH}_{3}\right), 3.79(2 \mathrm{H}, \mathrm{s}$, $\left.\mathrm{CH}_{2} \mathrm{CO}\right), 4.13\left(2 \mathrm{H}, \mathrm{q}, \mathrm{CH}_{2}\right) 6.27(1 \mathrm{H}, \mathrm{d}, \mathrm{Ar}-\mathrm{H} 3), 6.86(1 \mathrm{H}, \mathrm{t}, \mathrm{Ar}-\mathrm{H} 5), 7.06(2 \mathrm{H}, \mathrm{d}, \mathrm{Ar}-\mathrm{H} 4, \mathrm{NH}), 7.20$ $\left(2 \mathrm{H}, \mathrm{m}, \mathrm{Ar}-\mathrm{H} 6, \mathrm{Ar}-\mathrm{H} 4{ }^{\prime}\right), 7.53$ (2H, m, Ar-H3', Ar-H5'); ${ }^{13} \mathrm{C}-\mathrm{NMR}\left(101 \mathrm{MHz}, \mathrm{DMSO}-\mathrm{d}_{6}, \delta \mathrm{ppm}\right)$ : $172.00(\mathrm{O}=\underline{\mathrm{C}}), 143.26,137.54,131.36,131.06,129.65,128.19,126.36,123.72,121.13,116.35$ (Ar- $\underline{\mathrm{C}})$, $61.07\left(\mathrm{O}-\underline{\mathrm{CH}}_{2}\right), 37.63\left(\mathrm{Ar}-\underline{\mathrm{C}} \mathrm{H}_{2}\right), 14.55\left(\mathrm{CH}_{2}-\underline{\mathrm{CH}}_{3}\right) ; \mathrm{HR}-\mathrm{MS}: \mathrm{m} / \mathrm{z}$ calculated for $\mathrm{C}_{16} \mathrm{H}_{15} \mathrm{Cl}_{2} \mathrm{NO}_{2}$, $[\mathrm{M}+\mathrm{H}]^{+} 324.055261$, found 324.055286; TLC (petroleum ether:ethyl acetate $=9.0: 1.0 \mathrm{v} / \mathrm{v}$ ) $\mathrm{Rf}=0.78$.

Optimization of the synthesis of 2-[(2,6-dichlorophenylamino)phenyl]acetohydrazide (3) was performed using different procedures reported in the literature [17-19]. The influence of different parameters such as the ratio between ethyl 2-[2-(2,6-dichlorophenylamino) phenyl]acetate (diclofenac ethyl ester) (2) and hydrazine hydrate $64 \%(1: 1,1: 5,1: 11,1: 15,1: 20,1: 25)$, the temperature $\left(80^{\circ} \mathrm{C}\right.$ or $105^{\circ} \mathrm{C}$ ), the solvent (ethanol or dioxane), the time of reaction (between $30 \mathrm{~min}$ to $12 \mathrm{~h}$ ) and the method used (classic or microwave) on the reaction yield is presented in Table 2.

It was observed that the highest yield (90\%) was obtained using he following conditions: ratio between diclofenac ethyl ester (2) and hydrazine hydrate 64\% of 1 eq. : 20 eq., dioxane as solvent and heating at $105^{\circ} \mathrm{C}$ (reflux) for $6 \mathrm{~h}$. Using these conditions the compound 3 was obtained in yield which is higher than the value of $72 \%$ which was reported by other researchers $[5,6]$.

Table 2. The different reaction conditions used to optimize the reaction of diclofenac ethyl ester with hydrazine hydrate

\begin{tabular}{|c|c|c|c|c|c|c|c|}
\hline No. & $\begin{array}{c}\text { Diclofenac ethyl } \\
\text { ester }\end{array}$ & $\begin{array}{c}\text { Hydrazine } \\
\text { hydrate } \mathbf{6 4 \%}\end{array}$ & Solvent & $\mathbf{T}\left(^{\mathbf{0}} \mathbf{C}\right)$ & $\begin{array}{c}\text { Time } \\
(\mathbf{m i n} / \mathbf{h})\end{array}$ & $\begin{array}{c}\text { Method } \\
\text { used }\end{array}$ & Yield \\
\hline 1. & 1 eq. & 1 eq. & ethanol & 80 & $2 \mathrm{~h}$ & classic & nd \\
\hline 2. & 1 eq. & 5 eq. & ethanol & 80 & $4 \mathrm{~h}$ & classic & nd \\
\hline 3. & 1 eq. & 15 eq. & ethanol & 80 & $5 \mathrm{~h}$ & classic & $15 \%$ \\
\hline 4. & 1 eq. & 20 eq. & ethanol & 80 & $6 \mathrm{~h}$ & classic & $25 \%$ \\
\hline 5. & 1 eq. & 20 eq. & ethanol & 80 & $30 \mathrm{~min}$ & mw & $23 \%$ \\
\hline 6. & 1 eq. & 1 eq. & dioxane & 105 & $2 \mathrm{~h}$ & classic & nd \\
\hline 7. & 1 eq. & 5 eq. & dioxane & 105 & $3 \mathrm{~h}$ & classic & $16 \%$ \\
\hline 8. & 1 eq. & 10 eq. & dioxane & 105 & $4 \mathrm{~h}$ & classic & $25 \%$ \\
\hline 9. & 1 eq. & 15 eq. & dioxane & 105 & $3 \mathrm{~h}$ & classic & $46 \%$ \\
\hline 10. & 1 eq. & 20 eq. & dioxane & 105 & $2 \mathrm{~h}$ & classic & $65 \%$ \\
\hline 11. & 1 eq. & 20 eq. & dioxane & 105 & $4 \mathrm{~h}$ & classic & $80 \%$ \\
\hline 12. & 1 eq. & 20 eq. & dioxane & 105 & $6 \mathrm{~h}$ & classic & $90 \%$ \\
\hline 13. & 1 eq. & 20 eq. & dioxane & 105 & $9 \mathrm{~h}$ & classic & $79 \%$ \\
\hline
\end{tabular}




\begin{tabular}{|c|c|c|c|c|c|c|c|}
\hline 14. & 1 eq. & 25 eq. & dioxane & 105 & $6 \mathrm{~h}$ & classic & $77 \%$ \\
\hline 15. & 1 eq. & 20 eq. & dioxane & 105 & $45 \mathrm{~min}$ & $\mathrm{mw}$ & $82 \%$ \\
\hline
\end{tabular}

$\mathrm{T}\left({ }^{\circ} \mathrm{C}\right)=$ temperature; $\mathrm{mw}=$ microwave; $\mathrm{nd}=$ nondetected

Yield: $80 \%$; m.p.: $164^{\circ} \mathrm{C}$; IR $\left(\mathrm{cm}^{-1}\right): 3325\left(-\mathrm{NH}_{2}\right), 3155,3070,3024$ (-NH-), 2361, 1582, 1288 $\left(\mathrm{CH}_{\mathrm{Ar}}\right), 1636$ (-CO-NH), 987, 771, 741, (-C-Cl); ${ }^{1} \mathrm{H}-\mathrm{NMR}$ (400 MHz, DMSO-d 6 , $\delta$ ppm): 3.53 (2H, 2s, $\left.\mathrm{CH}_{2} \mathrm{CO}\right), 4.32\left(2 \mathrm{H}, \mathrm{d}, \mathrm{NH}_{2}\right), 6.31(1 \mathrm{H}, \mathrm{d}, \mathrm{Ar}-\mathrm{H} 3), 6.85(1 \mathrm{H}, \mathrm{t}, \mathrm{Ar}-\mathrm{H} 5), 7.04(1 \mathrm{H}, \mathrm{t}, \mathrm{Ar}-\mathrm{H} 4), 7.17(2 \mathrm{H}$, m, Ar-H6, Ar-H4'), 7.51 (2H, m, Ar-H3', Ar-H5'), $8.54(1 \mathrm{H}, 2 \mathrm{~s}, \mathrm{NH}), 9.49$ (1H, 2s, CONH); ${ }^{13} \mathrm{C}$ NMR $\left(101 \mathrm{MHz}, \mathrm{DMSO}-\mathrm{d}_{6}, \delta \mathrm{ppm}\right) 171.27(\mathrm{O}=\mathrm{C}), 143.44,137.68,130.81,129.74,129.67,127.71,125.83$, 125.42, 121.18, $116.52(\mathrm{Ar}-\underline{\mathrm{C}}), 38.13\left(\mathrm{Ar}-\underline{\mathrm{C}} \mathrm{H}_{2}\right)$; HR-MS: m/z calculated for $\mathrm{C}_{14} \mathrm{H}_{13} \mathrm{Cl}_{2} \mathrm{~N}_{3} \mathrm{O},[\mathrm{M}+\mathrm{H}]^{+}$ 310.050987, found 310.050844; TLC (petroleum ether : ethyl acetate $=8.0: 2.0 \mathrm{v} / \mathrm{v}$ ) $\mathrm{Rf}=0.10$.

Optimization of the synthesis of 2-[2-(2,6-dichloroanilino)phenyl]-N-[(E)-(4-methylphenyl) methylideneamino]acetamide (4i) was performed using different procedures reported in the literature [19-22]. The influence of different parameters such as the ratio between 2-[(2,6-dichlorophenylamino)phenyl]acetohydrazide (diclofenac hydrazide) (3), 4-methyl-benzaldehyde and glacial acetic acid, as catalyst, the reaction temperature $\left(65^{\circ} \mathrm{C}\right.$ or $\left.80^{\circ} \mathrm{C}\right)$, the solvent (methanol or ethanol), the time of reaction (between $30 \mathrm{~min}$ and $6 \mathrm{~h}$ ) and the method used (classic or microwave) on the reaction yield is presented in Table 3 .

It was observed that the highest yield $(92 \%)$ was obtained using the following conditions: ration between diclofenac hydrazide (3), 4-methyl-benzaldehyde and glacial acetic acid of 1 eq.: 1.5 eq. : 0.25 eq., ethanol as solvent and heating at $80^{\circ} \mathrm{C}$ for $2 \mathrm{~h}$. Using these conditions, the compound $4 \mathbf{i}$ was obtained in a yield which is higher than the value of $65 \%$ which was reported by other researchers, which didn't use the catalyst, and the ratio between diclofenac hydrazide and 4-methyl-benzaldehyde was $1: 2[5]$.

Table 3. The different reaction conditions used to optimize the reaction of diclofenac hydrazide with 4-methyl-benzaldehyde

\begin{tabular}{|l|l|l|l|l|l|l|l|l|}
\hline No. & $\begin{array}{l}\text { Diclofenac } \\
\text { acetohydrazid } \\
\text { e }\end{array}$ & $\begin{array}{l}\text { 4-methyl- } \\
\text { benzaldehyde }\end{array}$ & $\begin{array}{l}\text { Glacial acid } \\
\text { acetic }\end{array}$ & Solvent & T $\left(^{\circ} \mathbf{C}\right)$ & $\begin{array}{l}\text { Time } \\
(\mathbf{m i n} / \mathbf{h})\end{array}$ & $\begin{array}{l}\text { Method } \\
\text { used }\end{array}$ & Yield \\
\hline 1. & 1 eq. & 1 eq. & 0.20 eq. & methanol & 65 & $2 \mathrm{~h}$ & classic & $38 \%$ \\
\hline 2. & 1 eq. & 2 eq. & 0.30 eq. & methanol & 65 & $2 \mathrm{~h}$ & classic & $46 \%$ \\
\hline 3. & 1 eq. & 2 eq. & 0.50 eq. & methanol & 65 & $4 \mathrm{~h}$ & classic & $42 \%$ \\
\hline 4. & 1 eq. & 2 eq. & 0.25 eq. & methanol & 65 & 30 min & mw & $52 \%$ \\
\hline 5. & 1 eq. & 1 eq. & 0.10 eq. & ethanol & 80 & $1 \mathrm{~h}$ & classic & $55 \%$ \\
\hline 6. & 1 eq. & 1 eq. & 0.20 eq. & ethanol & 80 & $2 \mathrm{~h}$ & classic & $70 \%$ \\
\hline 7. & 1 eq. & 1 eq. & 0.30 eq. & ethanol & 80 & $3 \mathrm{~h}$ & classic & $65 \%$ \\
\hline 8. & 1.5 eq. & 0.20 eq. & ethanol & 80 & $1 \mathrm{~h}$ & classic & $68 \%$ \\
\hline 9. & 1 eq. & 1.5 eq. & 0.20 eq. & ethanol & 80 & $2 \mathrm{~h}$ & classic & $92 \%$ \\
\hline 10. & 1 eq. & 1.5 eq. & 0.20 eq. & ethanol & 80 & $4 \mathrm{~h}$ & classic & $88 \%$ \\
\hline 11. & 1 eq. & 2 eq. & 0.20 eq. & ethanol & 80 & $2 \mathrm{~h}$ & classic & $90 \%$ \\
\hline 12. & 1 eq. & 1.5 eq. & 0.20 eq. & ethanol & 80 & $1 \mathrm{~h}$ & mw & $89 \%$ \\
\hline
\end{tabular}

$\mathrm{T}\left({ }^{\circ} \mathrm{C}\right)=$ temperature; $\mathrm{mw}=$ microwave

Using the optimized method for 2-[2-(2,6-dichloroanilino)phenyl]-N-[(E)-(4-methylphenyl) methylideneamino]acetamide other diclofenac hydrazones were obtained. The physico-chemical characteristics of the synthetized diclofenac hydrazones are presented in our paper [23]. 


\subsection{Serum albumin denaturation assay}

The generation of autoantigens in rheumatic and inflammatory disorders can cause tissue protein precipitation, thus leading to the aggravation of these diseases. It was proved that any compound exhibiting a protein degradation inhibition greater than $20 \%$ can be further evaluated as a potential anti-inflammatory agent. Many NSAIDs drugs such as aspirin, diclofenac, indomethacin, flufenamic acid, in addition to the ability to inhibit the synthesis of protaglandins (cyclooxygenase inhibition), also showed an appreciable capacity to prevent BSA denaturation [24].

From the analysis of the obtained results (Figure 1) it is observed that for all studied derivatives, the inhibition of bovine serum albumin denaturation increases with the concentration, the highest inhibition being obtained at $125 \mu \mathrm{g} / \mathrm{mL}$. At this concentration the most active were $4 \mathbf{d d}(95.36 \% \pm$ $0.43 \%), 40(92.83 \pm 0.40 \%)$ and $\mathbf{4 n}(92.13 \pm 0.37 \%)$ which were more active than diclofenac $(85.67 \%$ $\pm 0.44 \%)$, used as a positive control.

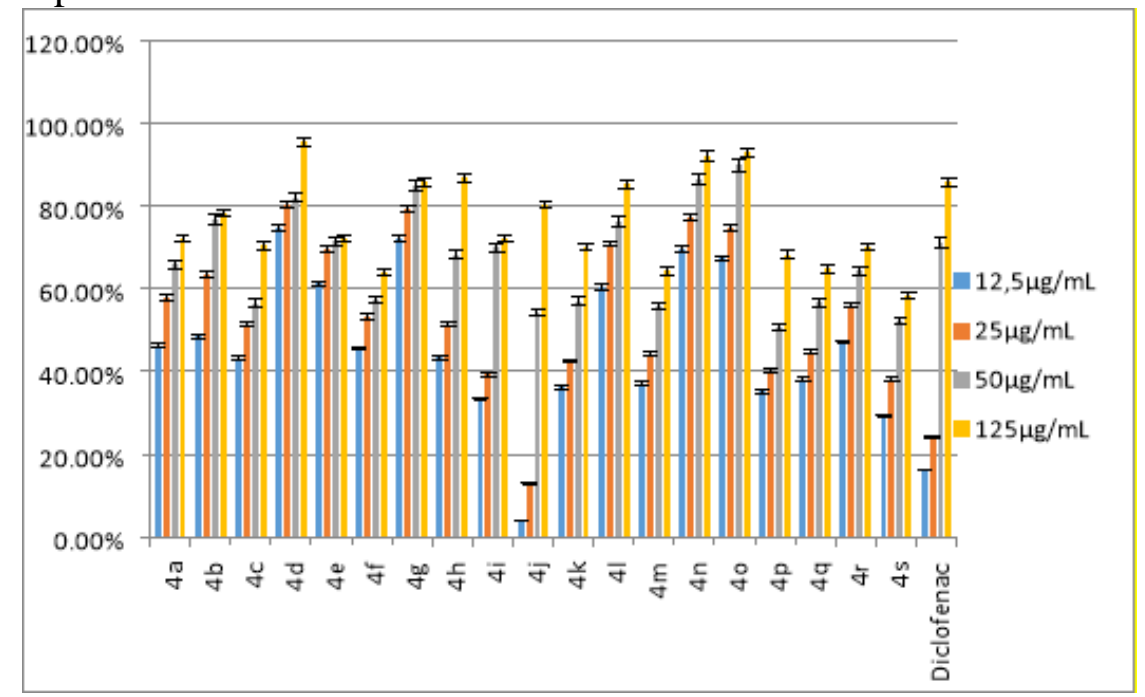

Figure 1. The inhibition (\%) of serum albumin denaturation by the diclofenac derivatives (4a-s)

From the analysis of the $\mathrm{EC}_{50}$ values (Table 4) we noticed derivatives $\mathbf{4 d}\left(\mathrm{R}=3-\mathrm{OCH}_{2} \mathrm{CH}_{3}-4-\mathrm{OH}\right.$, $\left.\mathrm{CE}_{50}=5.234 \pm 0.002\right)$ and $\mathbf{4 g}\left(\mathrm{R}=4-\mathrm{OCH}_{3}, \mathrm{EC}_{50}=5.887 \pm 0.016\right)$, for which the inhibition of bovine serum albumin denaturation is 7.40 times, respectively 6.60 times more intense than diclofenac $\left(\mathrm{EC}_{50}\right.$ $=38.776 \pm 0.022)$. Considerable inhibition effect was also noted for derivatives $4 \mathbf{e}\left(\mathrm{R}=4-\mathrm{Br}-2-\mathrm{NO}_{2}\right.$, $\left.\mathrm{EC}_{50}=7.321 \pm 0.008\right), 4 \mathbf{l}\left(\mathrm{R}=3-\mathrm{Br}-4-\mathrm{OH}, \mathrm{EC}_{50}=7.556 \pm 0.020\right)$ and $\mathbf{4 n}\left(\mathrm{R}=2-\mathrm{Br}-4-\mathrm{F}, \mathrm{EC}_{50}=9.237 \pm\right.$ 0.016), which are 5.30 times (4e), 5.10 times (4l) and 4.20 times (4n) more active than diclofenac.

Table 4. $\mathrm{EC}_{50}$ values $(\mu \mathrm{g} / \mathrm{mL}$ ) for diclofenac derivatives with hydrazone structure (4a-s), reffering to inhibition of bovine serum albumin denaturation

\begin{tabular}{|c|c|c|c|c|c|}
\hline No. & $\mathbf{R}$ & $\mathrm{EC}_{50}(\mu \mathrm{g} / \mathrm{mL})$ & No. & $\mathbf{R}$ & $\mathrm{EC}_{50}(\mu \mathrm{g} / \mathrm{mL})$ \\
\hline $4 a$ & $2-\mathrm{NO}_{2}$ & $16.631 \pm 0.012$ & $4 k$ & 3,4-diF & $37.871 \pm 0.021$ \\
\hline $4 b$ & 4-CN & $13.848 \pm 0.017$ & 41 & 3-Br-4-OH & $7.556 \pm 0.020$ \\
\hline $4 c$ & $3-\mathrm{NO}_{2}$ & $23.062 \pm 0.013$ & $4 m$ & $2,5-\mathrm{diBr}$ & $37.661 \pm 0.016$ \\
\hline 4d & $\begin{array}{c}3-\mathrm{OCH}_{2} \mathrm{CH}_{3}-4- \\
\mathrm{OH}\end{array}$ & $5.234 \pm 0.002$ & $4 n$ & $2-B r-4-F$ & $9.237 \pm 0.016$ \\
\hline $4 e$ & 4-Br-2-NO 2 & $7.321 \pm 0.008$ & 40 & 4-Br-2-F & $9.845 \pm 0.012$ \\
\hline $4 f$ & $2-\mathrm{Cl}-5-\mathrm{CF}_{3}$ & $19.771 \pm 0.009$ & $4 p$ & $3-\mathrm{F}-4-\mathrm{CH}_{3}$ & $48.653 \pm 0.014$ \\
\hline $4 \mathrm{~g}$ & $4-\mathrm{OCH}_{3}$ & $5.887 \pm 0.016$ & $4 q$ & 4-F & $36.181 \pm 0.011$ \\
\hline $4 \mathrm{~h}$ & $\mathbf{H}$ & $22.842 \pm 0.014$ & $4 r$ & 3-OCH $3-4-\mathrm{CH}_{3}$ & $16.671 \pm 0.005$ \\
\hline $4 \mathbf{i}$ & 4-CH3 & $33.793 \pm 0.019$ & $4 s$ & $\begin{array}{c}\text { 2-Br-3-OH-4- } \\
\mathrm{OCH}_{3}\end{array}$ & $46.464 \pm 0.019$ \\
\hline $\mathbf{4 j}$ & $3-\mathrm{CF}_{3}(4 \mathrm{j})$ & $47.381 \pm 0.022$ & & Diclofenac & $38.776 \pm 0.022$ \\
\hline
\end{tabular}

Data are mean $\pm \mathrm{SD}(\mathrm{n}=3, p<0.05)$ 


\subsection{Erytrocyte membrane stabilization test}

It is known the stability of lysosomal mebrane is crucial for limiting the inflammation. By destroying of the lysosomal membrane, the released cellular constituents activate neutrophils, bactericidal enzymes and proteases, causing destruction of cells and tissue inflammation. The erythrocyte membrane, which is similar to the lysosomal one, is commonly used as assay for assessing the anti-inflammatory effect [25-28].

From the analysis of the obtained results (Figure 2) it is observed that for all tested derivatives, the stability of the erythrocyte membrane increases with the concentration, the highest stability being obtained at the concentration of $111.11 \mu \mathrm{g} / \mathrm{mL}$. At this concentration the most active were $4 \mathbf{e}(97.42 \pm$ $0.23 \%), \mathbf{4 b}(96.74 \pm 0.40 \%), \mathbf{4 m}(90.46 \pm 0.45 \%)$ and $\mathbf{4 f}(87.73 \pm 0.39 \%)$ for which were more active than diclofenac $(50.61 \pm 0.28 \%)$.

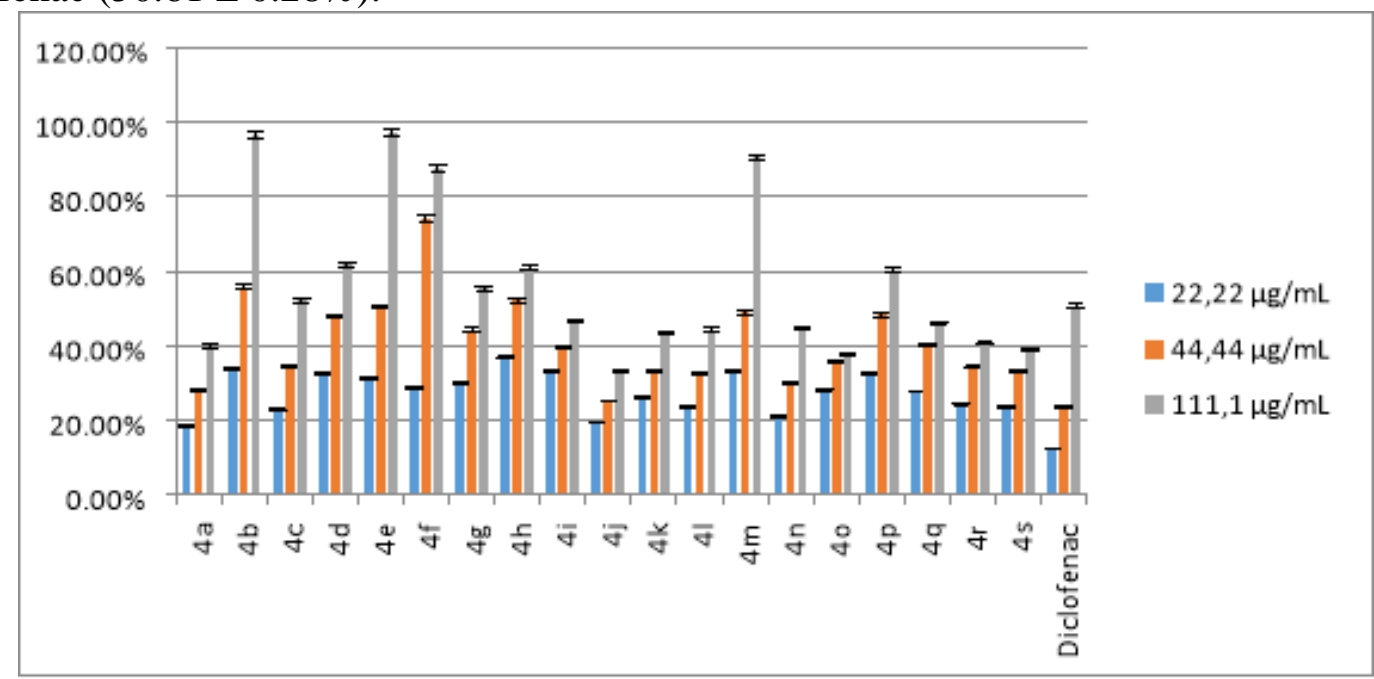

Figure 2. The stability capacity (\%) of the erythrocyte membrane induced by diclofenac derivatives (4a-s)

Table 5. $\mathrm{EC}_{50}$ values $(\mu \mathrm{g} / \mathrm{mL})$ for diclofenac derivatives with hydrazone structure (4a-s), reffering to erytrocyte membrane stabilization

\begin{tabular}{|c|c|c|c|c|c|}
\hline No. & $\mathbf{R}$ & $\mathrm{EC}_{50}(\mu \mathrm{g} / \mathrm{mL})$ & No. & $\mathbf{R}$ & $\mathrm{EC}_{50}(\mu \mathrm{g} / \mathrm{mL})$ \\
\hline $4 a$ & $2-\mathrm{NO}_{2}$ & $153.386 \pm 0.013$ & $4 k$ & 3,4-diF & $146.610 \pm 0.019$ \\
\hline $4 b$ & $4-\mathrm{CN}$ & $45.009 \pm 0.012$ & 41 & 3-Br-4-OH & $135.681 \pm 0.027$ \\
\hline $4 c$ & $3-\mathrm{NO}_{2}$ & $104.381 \pm 0.017$ & $4 m$ & 2,5-diBr & $48.178 \pm 0.021$ \\
\hline $4 d$ & $\begin{array}{c}\text { 3-OCH} \mathrm{CH}_{3}-4- \\
\mathrm{OH}\end{array}$ & $75.496 \pm 0.023$ & $4 n$ & 2-Br-4-F & $131.444 \pm 0.027$ \\
\hline $4 e$ & 4-Br-2-NO & $43.452 \pm 0.022$ & 40 & 4-Br-2-F & $221.268 \pm 0.013$ \\
\hline 4f & $2-\mathrm{Cl}-5-\mathrm{CF}_{3}$ & $32.260 \pm 0.006$ & $4 p$ & $3-\mathrm{F}-4-\mathrm{CH}_{3}$ & $77.831 \pm 0.019$ \\
\hline $4 g$ & $4-\mathrm{OCH}_{3}$ & $96.608 \pm 0.008$ & $4 q$ & 4-F & $131.356 \pm 0.031$ \\
\hline $5 \mathrm{~h}$ & $\mathbf{H}$ & $70.083 \pm 0.021$ & $4 r$ & $3-\mathrm{OCH}_{3}-4-\mathrm{CH}_{3}$ & $158.541 \pm 0.034$ \\
\hline $4 i$ & $4-\mathrm{CH}_{3}$ & $133.249 \pm 0.023$ & $4 s$ & $\begin{array}{c}\text { 2-Br-3-OH-4- } \\
\mathrm{OCH}_{3}\end{array}$ & $175.268 \pm 0.023$ \\
\hline $4 j$ & $3-\mathrm{CF}_{3}$ & $219.907 \pm 0.018$ & & Diclofenac & $109.684 \pm 0.019$ \\
\hline
\end{tabular}

Data are mean \pm SD $(n=3, p<0.05)$

From the analysis of the $\mathrm{EC}_{50}$ values (Table 5) we noticed the derivatives $\mathbf{4 f}\left(\mathrm{R}=2-\mathrm{Cl}-5-\mathrm{CF}_{3}, \mathrm{EC}_{50}=\right.$ $32.260 \pm 0.006)$ and $4 \mathbf{e}\left(\mathrm{R}=4-\mathrm{Br}-2-\mathrm{NO}_{2}, \mathrm{EC}_{50}=43.452 \pm 0.022\right)$ for which the stabilization capacity of the erythrocyte membrane is 3.40 times, and respectively 2.50 times more intense than diclofenac $\left(E_{50}=109.684 \pm 0.019\right)$. Considerable stabilization effect was also noted for derivatives $4 \mathbf{b}(\mathrm{R}=4$ $\left.\mathrm{CN}, \mathrm{EC}_{50}=45.009 \pm 0.012\right), \mathbf{4 m}\left(\mathrm{R}=2,5-\mathrm{diBr}, \mathrm{EC}_{50}=48.178 \pm 0.021\right)$ and $\mathbf{4 h}\left(\mathrm{R}=\mathrm{H}-, \mathrm{EC}_{50}=70.083 \pm\right.$ $0.021)$, these being 2.40 times $(\mathbf{4 b}), 2.30$ times $(\mathbf{4 m})$ and 1.60 times $(\mathbf{4 h})$ more active than diclofenac. 


\section{Conclusions}

By variation of different synthesis parameters such as: the ratio between reagents, catalyst, the solvent, the temperature, the time of reaction and the method used (classic or microwave), many chemistry procedures were developed in order to increase the yield of synthesis and the purity of diclofenac derivatives. The derivatives $\mathbf{4 d}\left(\mathrm{R}=3-\mathrm{OCH}_{2} \mathrm{CH}_{3}-4-\mathrm{OH}\right)$ and $\mathbf{4 g}\left(\mathrm{R}=4-\mathrm{OCH}_{3}\right)$, obtained by reaction of diclofenac hydrazide and 3-ethoxy-4-hydroxy-benzaldehyde and 4-methoxy-benzaldehyde respectively, showed the most intense effect on inhibition of serum albumin denaturation. In addition, compound 4d showed also a good stabilization effect on the erythrocyte membrane. An intense effect on stabilization of erythrocyte membrane, in reference to diclofenac, was also showed by derivative $\mathbf{4 f}$ $\left(\mathrm{R}=2-\mathrm{Cl}-5-\mathrm{CF}_{3}\right)$. The obtained results support that the chemical modulation of diclofenac structure had as result increasing the anti-inflammatory effects of some hydrazones derivatives, which opens new perspectives in the treatment of inflammatory diseases.

Acknowledgments.Scientific research was funded the grant of UEFISCDI, PN III Program, AUF-RO, AUF-IFA 2019-2020, contract no. 28/2019.

\section{References}

1.KOLODZIEJSKA, J., KOLODZIEJCZYK, M., Diclofenac in the treatment of pain in patients with rheumatic diseases, Rheumatology, 56(3), 2018, 174-183.

2. PEREIRA-LEITE, C., NUNES, C., REIS, S., Interaction of nonsteroidal anti-inflammatory drugs with membranes: in vitro assessment and relevance for their biological actions, Prog Lipid Res, 52(4), 2013, 571-584.

3.ANU, K., SUMAN, B., SUNIL, K., NEHA, S., VIPIN, S., Schiff Bases: A Versatile Pharmacophore, J Catal, 2013, 2013, 1-14.

4. CHINNASAMY, R. P., SUNDARARAJAN, R., GOVINDARAJ, R., Synthesis, characterization, and analgesic activity of novel Schiff base of isatin derivatives, J Adv Pharm Tech Res, 1(3), 2010, 342-347.

5. BHANDARI, S. V., BOTHARA, K. G., RAUT, M. K., PATIL A. A., SARKATE, A. P., MOKALE, V. J., Design, synthesis and evaluation of antiinflammatory, analgesic and ulcerogenicity studies of novel S-substituted phenacyl-1,3,4-oxadiazole-2-thiol and Schiff bases of diclofenac acid as nonulcerogenic derivatives, Bioorg. Med. Chem., 16, 2008, 1822-1831.

6.SRIRAM, D., YOGEESWARI, P., DEVAKARAM, R. V., Synthesis, in vitro and in vivo antimycobacterial activities of diclofenac acid hydrazones and amides, Bioorg. Med. Chem., 14(9), 2006, 3113-3118.

7.CHOWDHURY, A., AL MAMUN, A., RAHMAN, S., AZAM, S., SHAMS, K., JAINUL, A., Human red blood cell membrane stability testing for the estimation of anti-inflammatory activity of methanolic extract of Millettia pachycarpa Benth leaves, Int J Pharm Sci Res, 4(12), 2013, 4587-4590.

8. SUCHITA, V. G., MRUNAL, G. S., VARSHA, M. J., VILASRAO, J. K., NILAM, S., MIRA, R., Assessment of in-vitro anti-inflammatory activity of cynodon dactylon and acyclovir showing synergistic effect by albumin denaturation and membrane stabilization assay, Mod Appro Drug Des., 1(2), 2017, 1-5.

9.BAWA, S., KUMAR, S., DRABU, S., KUMAR, R., Synthesis and antimicrobial activity of 2chloro-6-methylquinoline hydrazone derivatives, J Pharm Bioallied Sci, 1(1), 2009, 27-31.

10.KAUTHAlE, S., TEKAlE, S., DAMALE, M., SANGSHETTI, J., PAWAR, R., Synthesis, antioxidant, antifungal, molecular docking and ADMET studies of some thiazolyl hydrazones, Bioorg Med Chem Lett, 27(16), 2017, 3891-3896.

11.MURTAZA, S., AKHTAR, M. S., KANWAL, F., ABBAS, A., ASHIQ, S., SHAMIM, S., Synthesis and biological evaluation of Schiff bases of 4-aminophenazone as an anti-inflammatory, analgesic and antipyretic agent, J Saudi Chem Soc, 21(1), 2017, 359-372. 
12. AWAREL, C., PATIL, R., GAIKWAD, S., YADAV, S., BAPAT, V., JADHAV, J., Evaluation of L-dopa, proximate composition with in vitro anti-inflammatory and antioxidant activity of Mucuna macrocarpa beans: A future drug for Parkinson treatment, Asian Pac J Trop Biomed, 7(12), 2017, 1097-1106.

13. MOUALEK, I., IRATNI, A. G., GUECHAOUI, N. M., LAHCENE, S., HOUALI, K., Antioxidant and anti-inflammatory activities of Arbutus unedo aqueous extract, Asian Pac J Trop Biomed, 6(11), 2016, 937-944.

14. ANITA, S. G., DESHMUKH, V. K., CHAUDHARI, S. R., Synthesis, characterization and in-vitro antiinflammatory activity of some substituted 1,2,3,4 tetrahydropyrimidine derivatives, Drug Invent Today, 5, 2013, 175-181.

15. AYDIN S., BASU, N. K., ARORA, P., BASU, A, TALELE, T. T., Microwave assisted synthesis of some novel flurbiprofen hydrazidehydrazones as anti-HCV NS5B and anti-cancer agents, Marmara Pharm J, 17, 2013, 26-34.

16. CHIKKAMATH, M. K., HAMPANNAVAR, G. A., PALKAR, M. B., Design, synthesis, and biological evaluation of novel diclofenac analogs as promising anti-inflammatory agents, Indian $J$ Health Sci Biomed Res, 12(1), 2019, 35-43.

17. CONSTANTIN, S., PANZARIU, A., VASINCU, I., APOTROSOAEI, M., CONFEDERAT, L., BURON, F., ROUTIER, S., PROFIRE, L., Synthesis and evaluation of antioxidant activity of some hydrazones with xanthine structure, Rev Med Chir Soc Med Nat, 119(3), 2015, 910-916.

18. NARANG, R., NARASIMHAN, B., SHARMA, S., A review on biological activities and chemical synthesis of hydrazide derivatives, Current Med Chem, 19(4), 2012, 569-612.

19. IENASCU, I. M. C., LUPEA, A. X., POPESCU, I. M., TOMAS, S. T., ZAMFIR, A. D., Synthesis and Characterization of Some New 2-Hydroxy-N-(3-Trifluoromethyl-Phenyl)-Benzamide Derivatives, Rev Chim, 59(1), 2008, 56-60.

20. ABDELGAWAD, M. A., LABIB M. B., ABDEL-LATIF, M., Pyrazole-hydrazone derivatives as anti-inflammatory agents: Design, synthesis, biological evaluation, COX-1,2/5-LOX inhibition and docking study, Bioorg Chem, 74, 2017, 212-220.

21. CASANOVA, B. B., MUNIZ, M. N., DE OLIVEIRA, T., DE OLIVEIRA, L. F., MACHADO, M. M., Synthesis and biological evaluation of hydrazone derivatives as antifungal agents, Molecules, 20(5), 2015, 9229-9241.

22. KRATKY, M., BOSZE, S., BARANYAI, Z., STOLARIKOVA, J., VINSOVA, J., Synthesis and biological evolution of hydrazones derived from 4-(trifluoromethyl)benzohydrazide, Bioorg Med Chem Lett, 27(23), 2017, 5185-5189.

23. FOCȘA, A., IACOB, A., VASINCU, I., CONSTANTIN, S., ANDRIESCU, L., SAVA, A., BURON, F., ROUTIER, S., PROFIRE, L., The antioxidant potential evaluation of diclofenac derivatives with hydrazones structure, Farmacia, 68(2), 2020, 329-334.

24. GOVINDAPPA, M., NAGA SRAVYA, S., POOJASHRI, M. N., SADANANDA, T. S., CHANDRAPPA, C. P., SANTOYO, G., et al, Antimicrobial, antioxidant and in vitro antiinflammatory activity and phytochemical screening of water extract of wedelia trilobata (L.) hitchc, $J$ Med Plants Res, 5(24), 2011, 5718-5729.

25. CHOPADE, A. R., SOMADE, P. M., SAYYAD, F. J., Membrane stabilizing activity and protein denaturation: A possible mechanism of action for the anti-inflammatory activity of Phyllanthus amarus, JKIMSU, 1, 2012, 67-72.

26. KAR, B., SURESH KUMAR, R. B., KARMAKAR, I., DOLA, N., BALA, A., MAZUMDER, U. K., HADAR, P. K., Antioxidant and in vitro anti-inflammatory activities of Mimusops elengi leaves, Asian Pac J Trop Biomed, 2(2), 2012, 976-980.

27. DRĂGAN, M., STAN, C. D., IACOB, A., PROFIRE, L., Assessment of in vitro antioxidant and anti-inflammatory activities of new azetidin-2-one derivatives of ferulic acid, Farmacia, 64(5), 2016, 717-721. 
28. UMAPATHY, E., NDEBIA, E. J., MEEME, A., ADAM, B., MENZIWA, P., NKEH-CHUNGAG, B. N.,IPUTO, J. E., An experimental evaluation of Albuca setosa aqueous extract on membrane stabilization, protein denaturation and white blood cell migration during acute inflammation, $J$ Med Plants Res, 4(9), 2010, 789-795. 